\title{
Metropolitan anxieties: a critical appraisal of Sartre's theory of colonialism
}

\author{
Mark Boyle* and Audrey Kobayashi**
}

\begin{abstract}
Within postcolonial studies there is now a well-established wariness of the Eurocentric or metrocentric tendencies of postcolonial theory itself. For some the charge that postcolonial theory continues to interpret the history and culture of non-European societies through European frames of reference can be traced to the provocative theory of colonisation developed by French philosopher, novelist and political activist Jean-Paul Sartre. We subject Sartre's theory of colonialism to critical scrutiny and question this claim. We locate Sartre's philosophical works and political activism against the backdrop of a twentieth-century Parisian intellectual life marked by fierce struggles over the future of Marxism. Sartre's metrocentricism was tempered by his tortuous efforts to write existentialism into the Marxist canon, a theoretical endeavour that led him to replace Marxism's eschatology and linear teleology with a series of circular histories based on the complex ways in which separate anti-colonial movements spiral off following their own contingent, creolised and anarchic trajectories. Sartre's desire to contest and rethink rather than submit to and seal metrocentric framings of colonialism and anticolonialism derived from his weddedness to a historicised phenomenology of existence as spatial. Critical interrogation of the complicity of postcolonial theory in the global march of metrocentric ontology affords both geography and postcolonial studies a new impetus for dialogue. Any project that aspires to a transcendence of metropolitan modes of knowing must first better understand the situated production and complexities of such modes of knowing. Before scrutinising how the colonising tendencies of postcolonial theory might best be handled, there is a need to map historical geographies of the different theoretical projects and practices that have emerged in different metropolitan locations and at different times.
\end{abstract}

key words $\begin{gathered}\text { Sartre } \\ \text { Marxism spolonialism postcolonialism existentialism } \\ \text { metrocentricism }\end{gathered}$
spatity

*Department of Geography National University of Ireland, Maynooth, Co Kildare, Ireland **Department of Geography, Queen's University, Kingston, Ontario, Canada K7L 3N6 email: mark.g.boyle@nuim.ie

revised manuscript received 2 November 2010

\begin{abstract}
For my generation, he has always been one of the great intellectual heroes of the 20th century, a man whose insight and intellectual gifts were at the service of nearly every progressive cause of our time. Yet he seemed neither fallible nor prophetic. On the contrary, one admired Sartre for the efforts he made to understand situations and, when necessary, to offer solidarity for political causes. He was never condescending or evasive, even if he was given to error and overstatement. Nearly everything he wrote is interesting for its sheer audacity, its freedom (even its freedom to be verbose) and its generosity of spirit. (Said 2000, 1)
\end{abstract}

\section{Introduction}

Since the publication of Said's Orientalism in 1978, geography and postcolonial studies have combined to excavate the geopolitical imaginaries and global projections that Europe (the West) mobilised and continues to mobilise to legitimate colonial adventures, build hegemonic projects and manufacture consent (Said 1978). Moreover, postcolonial studies has stimulated Anglo-American geography itself to reflect on its own emergence in and through 
empire, and by encouraging a historicising and relativising of geographical imaginations spawned from within professional and institutional wings of the discipline has sought to raise awareness of the complex ways in which Anglo-American geography has intermeshed with histories of colonialism and empire. Collectively, this body of work has effectively and critically deconstructed European ways of imagining, demonising and belittling other, non-European, and past and present colonised societies.

Nevertheless, as revealed in the proliferation of such mantras as 'unthinking Eurocentricism', 'history without a centre' and 'provincialising Europe', within postcolonial studies there is now a wellestablished wariness that in spite of its professed critical and radical ambitions, postcolonial theory itself might be open to the charge that it too is guilty of interpreting the history and culture of non-European societies principally through European frames of reference. While aspiring to a decentring of the sovereign supremacy assumed by the European geographical imagination, postcolonial theory, it seems, continues to fall prey to a certain kind of Eurocentricism or metrocentricism, defined here as a set of theoretical practices predicated on an insufficiently reflexive commitment to the superiority of particularly European ways of rendering the world intelligible. Postcolonial theory, it is feared, remains dogged by a certain Eurocentric and colonial mentality.

One limit of postcolonial theory stems from its reification of conceptual frameworks that betray specifically European treatments of time and space. Chakrabarty labels these treatments 'historicism', defined as a

mode of thinking about history in which one assumed that any object under investigation retains a degree of unity of conception throughout its existence and attains a full expression through a process of development in secular historical time. (Chakrabarty 2007, 11)

Postcolonial theory asserts proprietorial control and authority over the right to apprehend the meaning of all concrete colonialisms and anti-colonialisms. Postcolonial theory gathers together a variety of different territorial annexations, labels them collectively as 'colonialism', 'imperialism' and 'neocolonialism', frames them as instances of a singular universal process, and explains them with reference to an overarching master narrative. In so doing, it sabotages its capacity to render legible the trajectory of territorial dispossessions and acquisitions, resistances and counter insurgencies that might in reality be unique, particular and specific.

How to handle the colonising tendencies of postcolonial theory has emerged as a central concern for postcolonial scholars, especially within Indian contributions to postcolonial scholarship, where the charge of metrocentricism has been particularly and forcibly articulated. Spivak (1997) of course has commented on the incommensurability of Western theory and non-Western subalterns, and questioned whether radically marginalised and disenfranchised (Indian) women in particular might ever speak to or more accurately be heard by Western audiences. More recently, Chakrabarty (2007) has proposed a two theories of colonialism approach that explores productive tensions between history 1 and history 2, where history 1 is based on universal historical logic, for instance, Marx's reading of capitalism, while history 2 is constitutive of numerous other tendencies in history that do not necessarily follow the telos of capital. Meanwhile, and with specific respect to South America, Mignola (1995) has placed the 'grammar of decoloniality' under scrutiny and championed the importance of social movements that emerge from forms of 'border thinking' that refuse both European coloniality and European modernity. Likewise Cooper (2005) has advocated a celebration of a 'politics of difference' that foregrounds colonialism's variety of cultures, the diversity of colonial and imperial strategies, the material geographies of annexation and control that result, variations in the form and strategies of anti-colonial movements and resistances, and geographically differentiated experiences of decolonisation and independence.

A key weakness of projects that seek to identify, critique and respond to metrocentricism within postcolonial theory is the assumption that to a meaningful degree European ways of apprehending the world are largely coherent and monolithic. In historicising and relativising Eurocentric scholarship, critical scholars often gloss over important spatial and temporal variations in European theoretical framings and practices (Withers 2007). In fact, the counter claim that different manifestations of European modernity have given birth to different traditions of postcolonial theory provides both geography and postcolonial studies with a new impetus for dialogue (for a review of dialogue to 
date see Blunt and McEwan 2002; Kearns 2009; McEwan 2008; Minca 2003; Nash 2004; Pickles 2005; Pollard et al. 2009; Sidaway 2000). There is a pressing need to write historical geographies of theories of colonialism that at once interrogate, critique and provincialise Eurocentric framings of the world, while at the same time take seriously the range of different and complex theoretical projects and practices that have emerged in different metropolitan locations and at different times.

More specifically, now is an opportune moment to better understand the situated production of treatments of time and space, especially as these treatments bear on theories of colonialism, at different times and in different places in Europe's emergence, mutation and decline. Of course, this project has occupied the attention of Massey (2005), who has sought to excavate from European modernity, alongside dominant species of historicism, treatments of time and space that approach space as a progenitor of history rather than an instantaneous freeze frame or simple slice through temporal processes. There is a pressing need to further develop Massey's archaeology of formulations of space and time within European modernity while at the same time critically evaluating how these formulations have both underpinned and in turn have been constituted by metropolitan apprehensions of the colonial problem. The objective is not to make the case for a revalorising of theories of colonialism produced and circulated from a European vista, but instead to scrutinise, qualify, specify and ruminate on the circumstances, conditions, terms and bases under which such theories might offer insights that are meaningful, useful and progressive.

Postcolonial studies is customarily traced to the foundational works of Fanon, Memmi, Du Bois, Gramsci and Said, translated and amplified by among others Bhabha, bell hooks, Spivak, Gilroy and Young. In contrast, the seminal role played by French philosopher, novelist and political activist Jean-Paul Sartre (1905-1980) has been largely overlooked and obfuscated (Majumdar 2007). This neglect has proven fatal, as for some the charge that postcolonial theory remains wedded to metrocentric theoretical constructs must ultimately be traced to Sartre. According to Wehrs, for instance,

the dominant conceptual frameworks of postcolonial theory remain tethered to assumptions embedded in the first form of anti-colonial theory to assume a major role in western intellectual history, that of Jean-Paul Sartre and his associates. (Wehrs 2003, 763)

\section{Likewise for Young,}

while postcolonial theory customarily traces its overt intellectual and political origins through more recent theoretical developments back to Fanon, Memmi, Du Bois, Gramsci, and Marx, the historical as well as the theoretical significance of Sartre's role and influence remains undervalued and unexamined. (Young 2001, VII)

The purpose of this paper is to rescue Sartre from critics who are too quick to indict his shadow as a significant point of origin of postcolonial theory's general inability to make sense of the histories of societies that dwell beyond the West. We seek to frame Sartre's theory of colonialism against the backdrop of a particular brand of twentieth-century French, and in particular Parisian, intellectual and political life, consumed with the future of Marxism. We contend that Sartre's imbrication in fierce struggles over the status of Marxism led him to a theory of colonialism that contested and rethought rather than submitted to and sealed metrocentric fetishisations of historicism. We contend that Sartre's philosophical commitment to a historicised phenomenology of existence as spatial lies at the root of his departure from historicism. For Sartre, conceptions of space and time vary as colonial projects unfold and these conceptions play a central role in the rise and fall of such projects. Our mission is to use Sartre, struggles within the Parisian academy and twentieth-century French colonial politics to clarify the case for and against criticising Sartrean thought as metrocentric and therein to build an argument in favour of heightening awareness of the variegated forms of European modernity and the variegated theoretical enterprises these forms have secreted.

This paper is divided into four sections. The first three sections sequentially build, illustrate and question the claim that Sartre's postcolonial theory serves in important ways as a debilitating entrée for postcolonial studies. Throughout, our intention is to locate and situate Sartre's thinking on colonialism against the backdrop of an intellectually, politically and militarily turbulent twentiethcentury Paris. In the first section, we argue that Sartre's interest in colonialism was motivated by a concern to rescue what he viewed as an authentic Marxism from its deviant, tyrannical, fossilised and 
crystalline secretion in Stalinist Russia and to find a new basis for Marxist historical teleology. In the second section, we examine Sartre's political writings and activism, and identify themes that have come to be recognised as Sartrean universals. In the third section, we argue that at a key moment in his intellectual journey Sartre rejected historicism and recast the theory of colonialism to be a theory of 'totalising without totalisation'. In the final section, we argue that Sartre's theory of colonialism constitutes and is constitutive of a particular theory of spatiality that permits him to approach time as radically open to newness.

\section{The purpose of Sartre's theory of colonialism: Sartre's intellectual journey from Existentialism to Existential Marxism}

Sartre's two principal philosophical works were Being and nothingness (first published in 1943) and the Critique of dialectical reason - hereinafter to be referred to as the Critique). Being and nothingness, of course, continues to stand as the definitive outline of existentialism; the Critique of dialectical reason, Sartre's Marxist work, by contrast, is only now getting the recognition it deserves. Although comprising one single project, the Critique in fact encompasses three different 'books' and two different 'volumes'. The problem of method was first published in 1957 (first translated into English in 1964) and subsequently reappeared as an introduction to Volume 1 of the Critique. The Theory of practical ensembles, which made up the body of Volume 1, was first published in 1960 (first translated into English in 1976). Volume 2 of the Critique, titled The intelligibility of history, was first published posthumously by Arlette Elkaïm-Sartre in 1985 (first translated into English in 1991). The entire project remained unfinished and it has to be remembered that Volume 1, and especially Volume 2, had to be heavily edited before publication.

In one of his most celebrated passages in Being and nothingness, Sartre $(1943,59)$ ponders the performance of a waiter in a café. What, Sartre muses, is this waiter 'playing at':

We need not watch long before we can explain it; he is playing at being a waiter in a café. There are indeed many precautions to imprison a man [sic] in what he is, as if he lives in perpetual fear that he might escape from it, that he might break away and suddenly elude his condition. (Sartre 1943, 59)
From this apparently banal example, Sartre comes to frame alienation in terms of the twin concepts of nausea and bad faith, the pillars of his existentialist philosophy. By nausea, Sartre means the profound sense of anguish, vertigo and terror that people feel when they come to glimpse the contingency and absurdity of their existence and the awesome responsibility they have by dint of their absolute freedom. Unable to bear this burden, human beings forsake 'being for themselves' and become 'beings for others', and shelter in the safer waters of bad faith.

By the time he came to write the Critique, Sartre had undergone a transition; from a philosopher of human freedom to an activist intellectual concerned with social and political critique and action. Being and nothingness had established the conditions under which human beings initiate relations of alienation and projects searching for freedom. But freedom now needed to be more firmly founded in the social; it could never be realised at the level of the individual through existential psychoanalyses, deep individual meditation or self mastery, and could only be addressed by social and political movements capable of changing underlying social and economic structures; in our age, capitalism. Recognising the importance of his internment in a prisoner of war camp in France under German occupation, Ronald Aronson dates Sartre's conversion to the early 1940s and characterises it as a somewhat drawn out affair:

In slow, definitive stages, between 1940 and 1957, Sartre first became committed to political activism, to socialism, to developing an integration of thought, writing and action, to building a non communist democratic social movement, to close relations with the communist party and the Soviet Union, to using Marxism as a tool of analyses, and then in Search for a method and the Critique, to Marxism as a Philosophy. (Aronson 1987, 236)

Sartre himself identified Maurice Merleau Ponty's 1947 Humanism and terror: an essay on the Communist problem (see Merleau Ponty 1990) as the critical moment in his transition. It was during this period that he also published Materialism and revolution (first published in 1946, see Sartre 1955) and What is literature? (first published in 1947, see Sartre 1988), two key texts announcing a radical departure from (although not a repudiation of) Being and nothingness. By 1952, and prompted by the decision of the French government to suppress the French Communist Party in the wake of anti-NATO riots 
in Paris, Sartre wrote The Communists and peace, in which he 'swore to the bourgeoisie a hatred which would only die with me' (Sartre 1969, 128). These works were the precursor to The problem of method and finally, in the late 1950s, the Critique of dialectical reason itself (for an extended mapping of Sartre's transition, see Badiou 2007; Catalano 1986; Chiodi 1976; Craib 1976; Fatouros 1965; Flynn 1997; Fox 2003; Gerassi 1989; Lawler 1976; McBride 1981; Poster 1975).

Sartre's thinking evolved against the wider backdrop of the emergence of a new tradition of Western Marxism, that which might loosely be termed French Existential Marxism (Poster 1975). French Existential Marxism came to prominence during the period 1956 (the date of the Soviet invasion of Hungary) to about May 1968 (the student uprising in Paris). Alongside Edgar Morin, Pierre Fougeyrollas, Jean Duvigand and Henri Lefebvre, Sartre emerged as a key thinker within the tradition. French Existential Marxism arose in part as a reaction to the degeneration of the Communist Party in Stalinist Russia into a crippling bureaucracy and imperial oppressor. The French Existential Marxists were free thinkers within the Marxist tradition, critics of dogmatic French and Soviet communism, non-conformist Communists and eventually non-Communist Marxists. French Existential Marxists sought to rescue Marxism from its growing critics by offering an alternative to Soviet Communism. Scholarship and debate centred on alienation and its transcendence; the challenge of freeing the mystified consciousness of fetishisms, reifications and obfuscations through social and political practice. They believed that Marx's historical teleology was correct, but that the transition to a socialist society was not hard-wired into capitalism's contradictions and would occur only through active struggles around alienation.

In the search for a rejuvenated Marxism, French Existential Marxists turned to the sociology of modern Western society, and in particular focused on the one-dimensionality of existence in the age of technology, commodification and bureaucratisation. By contrast, Sartre was drawn to the problem of colonialism, convinced that colonisation, rebellion and resistance heralded a profoundly significant moment in the unfolding of history. For Sartre, anticolonial struggles were the only true heirs of authentic Marxism; only in the colonies might the genuine historical potential of Marxism be fulfilled. Anticolonial movements then were not to be approached as local and specific, but always as part of a univer- sal global transition from capitalism to socialism. It is little surprise then that towards the end of Volume 1 of the Critique, Sartre dedicates a section to 'Racism and colonialism as praxes and process', which specifically uses the case of colonialism to support the theses he was developing. Racism and colonialism were the social forms of modern human oppression.

Sartre's conversion to Marxism and his desire to put existentialism to the service for rescuing Marxism was mediated in particular ways by his disputations and solidarities with Maurice MerleauPonty (1908-1961) (Aronson 2004; Kelly 1999; Stewart 1998). Sartre had become friends with Merleau-Ponty as early as 1927 when they studied in Paris at the École Normale Supérieure, and together they had co-founded the journal Temps Modernes. Merleau-Ponty was at this point more politically aware and engaged, and Sartre attributed to him 'the push needed to release me from my immobility' (Sartre 1966, 198). But their relationship was to sour. In 1953, following a disagreement over editorial policy, Merleau-Ponty resigned as Co-Editor of Temps Modernes. This fallout was to intensify into a deep-seated philosophical antagonism and from 1953 to 1956 Merleau-Ponty began a bitter critique of Sartre's supposed fanatical Marxism.

From 1940, Merleau-Ponty had begun to view the Soviet Union as a distortion or detour or perversion of the real Marxist course of history and had adopted what was referred to as a 'wait and see' approach to Soviet Marxism. By 1955 he saw no reason to continue to wait. Appalled by the brutal oppression of the Stalinist regime and by Soviet imperialism in Eastern Europe, Merleau-Ponty announced his rejection of Marxism and Communism in his famous Les aventures de la dialectique (Merleau-Ponty 1955). The Soviet Union was not an aberrant instance; it held the truth about the inability of Communism to deliver emancipation. Merleau-Ponty dedicated an entire chapter to Sartre's thought and taunted him for his 'ultrabolshevism'. Sartre, he alleged, was at sea philosophically and politically. Philosophically, he continued to defend the sovereignty of individual consciousness and freedom, while at the same time supporting the idea that history has meaning and that capitalism is hard-wired from the outset to metamorphose into Communism. Moreover, politically, Sartre was trying to find freedom in the social world precisely where it was being corroded.

Curiously, Sartre was never to respond to Merleau-Ponty's attack, although Simone de 
Beauvoir did, accusing Merleau-Ponty of presenting, in bad faith, a 'pseudo Sartreanism'. Sartre's only official response came in his moving eulogy Merleau-Ponty vivant following Merleau-Ponty's sudden death in 1961, in which it became clear that the pain of losing his erstwhile friendship had contributed to his silence (see Sartre 1998). Nevertheless, while not offered as such, it is clear that the Critique of dialectical reason was Sartre's reply. That he undertook this momentous project reveals the depth to which Merleau-Ponty's attacks had shaken his confidence. Writing at a furious pace and recklessly medicating himself to counter fatigue, Sartre dedicated his energies to putting existentialism to work to solve some of the core weaknesses of historical materialism. His mission was to establish a basis for the claim that there could be 'totalisation' (an end to history) even if there was no 'totaliser' (an inner mechanism determining the transition). History could be rendered intelligible even if it was always only an aggregate outcome of molecular struggles.

Sartre's theory of colonialism then was motivated principally by his concern to develop a Marxist theory of colonialism and imperialism that would be capable of rescuing Marxism from its tyrannical, fossilised and crystalline degeneration under Stalin in the Soviet Union. Sartre's Marxism remained committed to historical teleology and the inevitability of the defeat of capitalism, and to the establishment of a global socialist society. Anticolonial movements throughout the world were to be interpreted as staging posts in this transition. All particulars were part of a universal process. All struggles were in the end struggles over capitalism and freedom for the colonised was freedom for the labourer. Defeat of colonialism was in crucial ways defeat of capitalism. Colonialism was the battle ground in which history itself was being fought out. But Sartre's desire to account for the anthropology of the social and political movements that would change the world and his turn to existentialism as the key to a redeemed Marxism, when deliberated on and reasoned to conclusion, eventually led him to a different set of conclusions.

\section{Sartrean universals and postcolonial lore: Sartre's political writings on colonialism and activism}

France was present in Algeria for 124 years before the nationalist uprising of 1954, and in the ensuing 8-year War of Independence, 250000 Algerians and 25000 French soldiers were killed (Cohen 2003). It is often presumed that Sartre's thinking on colonialism was most fundamentally shaped by the French colonial adventure in Algeria, and undoubtedly Sartre's interests in racism, negritude and 'tricontinentalism' bear the stamp of dramas of the Algerian War of Independence (French nationalists twice bombed his flat in Paris; he escaped injury on both occasions). But Sartre wrote and spoke prolifically, publicly and polemically about imperialism and colonialism in a variety of different twentieth-century contexts. His interests extended in particular to the rise and fall of Nazi Germany (he had an interest in anti-semitism, enlisted for the French army, was held as a prisoner of war and escaped to join the French resistance), the Cuban revolution (he visited Fidel Castro for a month in spring 1960 and was a keen student of the then youthful Cuban revolution), the Maoist revolution in China (from 1949 Sartre searched in Maoism for an alternative to Stalinism), and Vietnam (in Stockholm in May 1967, Sartre served as Executive President of the Russell International War Crimes Tribunal and charged the US with war crimes in Vietnam and Cambodia).

Because Sartre insisted that colonialism and anticolonialism had to be rendered intelligible as part of the wider meaning of history, his substantive writings and political activism are littered with programmatic statements asserting the universality of specific territorial sequestrations. Drawing on a range of his more important substantive interventions, this section identifies Sartrean themes that have become de facto lore within postcolonial studies today. These include: the claim that colonialism is a political system designed to support particular capitalist practices; that this system is predicated on a Manichaean dependency between coloniser and colonised that alienates both; that colonialism creates conditions in which anti-colonial violence is inevitable and legitimate; and that anti-colonial movements need to renounce their ethnic consciousness and cultural heritage if they are to comprehend their wider role in the unfolding of history.

Sartre delivered 'Colonialism as a system' at a rally for peace in Algeria in Wagram in 1956 and published this speech in Temps Modernes in the same year (Sartre 2001). This paper set out starkly the claim that French annexation of Algeria was driven by a systematic political agenda designed in France in the first instance by Jules Ferry, the 
famous figure of the Third Republic, to support and defend French capitalism and its drive towards accumulation by dispossession. Rejecting those who obfuscate by speaking in terms of varieties of colonialisms, Sartre asserts:

The fact is that colonization is neither a series of chance occurrences nor the statistical result of thousands of individual undertakings. It is a system which was put in place around the middle of the nineteenth century, began to bear fruit in about 1880 , started to decline after the First World War and is today turning against the colonizing nation. It is not true that there are some good colons and others who are wicked. There are colons and that is it. (Sartre 2001, 31-2)

Sartre outlined the systematic and orchestrated ways in which French annexation of Algeria, by sequestration, confiscation and unfair commercial transactions, was driven by a will to source cheap raw materials and to produce new and safeguarded markets for French goods. The French privatised property, erasing and replacing complex tribal claims to land ownership with a European mathematical calculus and set of cartographic metrics. French control over Algerian landed estates and the agro-industry then ensured that French capital could expand its investment in cash crops such as citrus fruits and viticulture beyond what was possible in France alone, and could penetrate new markets. The indigenous Algerian Muslim population, meanwhile, were driven either to form an immense agricultural proletariat or to eke livings off less productive soils in the interior of the country, beyond the reach of new irrigation systems.

Sartre recognised the central role that racism played in the legitimation of colonial endeavours. Metropolitan France reconciled any conscience about plundering Algeria by depicting the Algerian population as illiterate, uncivilised, primitive and barbaric. There was a development lag between Europe and the rest of the world, and it was a duty of Europe to spread the message of progress. A sub-human population did not require the protection of universal human rights, which extended only to the civilised world. The key assumptions of Western liberal humanism did not extend to Africa. In his devastating 1961 Preface to Fanon's Wretched of the earth (see Sartre 2001), Sartre undergirds the importance of European assumptions about the sub-humanity that existed beyond Europe:

You know very well that we are exploiters. You know very well that we took the gold and the metals and then the oil of the 'new continents', and brought them back to the old mother countries. Not without excellent results: palaces, cathedrals, industrial capitals; and then whenever crises threatened, the colonial markets were there to cushion or deflect it. Europe, stuffed with riches, granted de jure humanity to all its inhabitants. What empty chatter: liberty, equality, fraternity, love, honour, country, and who knows what else? That did not prevent us from holding forth at the same time in racist language: filthy nigger, filthy Jew, filthy North African. We saw in the human race an abstract principle of universality which served to conceal more realistic practices: there was on the other side of the seas, a race of sub humans who, thanks to us, in a thousand years would perhaps reach our status. (Sartre 2001, 151)

Sartre was especially interested in the wider production of culture that accompanied conquest. He recognised that colonial literature, poetry, theatre, music, drama, film, museums, archives and photographs were central tools of oppression, perhaps every bit as oppressive as military violence and intimidation. Written as a 1954 Preface to CartierBresson's From one China (see Sartre 2001), Sartre considers the ways in which picturesque photographs of China and the Chinese were used to objectify and exoticise that country and its people, and thereby to legitimate certain kinds of Western interventions. This work reveals the deconstructive finesse and semiotic subtlety Sartre was capable of bringing to bear on the cultural products deposited by colonising and capitalist elites (Sartre 2001).

For Sartre, agitators and activists had a duty to wrestle control of cultural production back from their oppressors. In What is literature (see Sartre 1988), Sartre insisted that all literary writers had an obligation to be politically committed and that the central purpose of literature was to effect social and political change. Colonialism and anti-colonial struggles were at the heart of Sartre's monumental literary work, The roads to freedom, for which he was awarded but rejected the Nobel Prize for Literature in 1964. Constructed around three novels, The age of reason (1945), The reprieve (1945) and Iron in the soul (1949) (Sartre would never finish his fourth instalment, the novel The last chance, but two chapters were published in 1949 Temps Modernes under the title Drôle d'amitie), the Roads to freedom is set within a Paris preparing for World War II, 19381940. From peace and false dawns to war and defeat, and from Nazi occupation to the search for liberation, Sartre charts the changing structures of feeling experienced by a number of central characters, 
most notably Parisian Mathieu Delarue, but also major historical figures including Chamberlain, Daladier and Hitler. He depicts a steady movement from apathy, insularity and private anguish to a recognition of a shared plight and a public awareness of the dignity of communal resistance.

Sartre was one of the first critics to recognise that it was not only the colonised that existed in alienation. In his 1957 review of Albert Memmi's The colonizer and colonized, which became a Preface to the 1966 edition of this book, Sartre laments the pitiless reciprocity that binds the colonizers to the colonized .... the impossible dehumanization of the oppressed turns against the oppressors and becomes their alienation' (Sartre 2001, 53). Reduced to violence, torture and racism to protect their newfound riches, colonisers themselves had lost their humanity. For Sartre both the coloniser and colonised had become interlocked in a deadly Manichaean tango that had rendered them inert; both had become casualties of colonialism and imperialism's insidious tendency to dehumanise. Ultimately, emancipation needed to be jointly authored.

Sartre's 1961 Preface to Fanon's Wretched of the earth continues to stand as his most brutal and controversial statement on the necessity for anti-colonial movements to embrace violence as part of their struggle. But Sartre's views on violence were long in maturation (Aron 1975; Santoni 2003). His great fallout with fellow existentialist Albert Camus provided a significant moment in his advocacy of violence as a legitimate means to an end. Estranged from his native Algeria on account of the Second World War, Camus temporarily joined the Communist Party and agitated in diaspora against French colonial oppression of his homeland. But Camus was to become increasingly hostile to violent social and political upheaval and steadily adopted a socially conservative stance. In his philosophical essay The rebel (first published in 1951, see Camus 1992), Camus called for 'rebellion without revolution' and championed the many small victories that could be secured if utopian aspirations were to give way to more conservative and incremental challenges within capitalist societies and colonial systems.

Sartre rebuked Camus for his lack of political commitment, claiming that only those involved in struggle had the right to pass comment on the virtues and vices of those who struggle. Sartre collaborated with Francis Jeanson, whose 1952 Temps Modernes article attacked Camus as naïve (Jeanson
1952). Later, when Jeanson's followers, known as the Jeanson Network, were put on trial in France for their support of the Front de Libération Nationale (FLN), Sartre wrote a support letter, again justifying the violence on the grounds that the FLN was a movement toward an end that represented not only the freedom of Algeria but also the freedom of France, which he viewed as having fallen under de Gaulle into a 'progressive diminution in liberties, the disappearance of political life, the generalization of torture, and the permanent insurrection of the military power against the civil power' (first published 1960, see Sartre 1961). In 1958 in L'express, Sartre published 'A victory' (see Sartre 2001), a written response to Henri Alleg's La question (Alleg 1958), which was published in same year and drew on first-hand experience to reveal the extent of French use of torture in Algeria. For Sartre, Alleg's testimony was affirmation that violence was necessary as a redemptive recovery of the lost humanity of the oppressed.

In reaction to Nazi racialisations of the Jewish population, in 1946 Sartre wrote Anti-Semite and Jew (see Sartre 1948), which offered the claim that it was the anti-semite who created the Jew rather than the Jew who had created the anti-semite. The objective of the Jew was to recover his or her authentic pre-racialised self. Black Orpheus (Orphée Noir) was written in 1948 (see Sartre 1976b) as an introduction to the Anthologie de la Nouvelle Poésie nègre et malgache de langue française edited by Léopold Sédar Senghor, a future Senegalese President (Senghor 1948). It was Sartre's most significant engagement with the negritude movement, a literary and ideological movement developed by francophone black intellectuals, writers and politicians in France in the 1930s by a group that included, alongside Senghor, Martinican poet Aimé Césaire, Congolese independence leader Patrice Lumumba and the Guianan Léon Damas. In Black Orpheus, Sartre again claimed that it was the racist who had created the coloured person and not the coloured person who had created the racist. The task of the negritude movement was to recover the authentic experience of the black person.

Although Anti-Semite and Jew and Black Orpheus appear at first sight to endorse an essentialising of Jewish and black identity, it is immediately clear that Sartre approached both with a wider objective. For Sartre, independence movements aspiring to 'decolonise the mind', to purge the cultural influences of Europe from the 'periphery', and to restore 
pre-colonial cultural forms, risked lapsing into a misguided conception of human freedom. Sartre recognised that black experience of oppression was distinctive from that endured by the white proletariat. African poetry was incommensurable with European epistemology. But in spite of recognising the particularity of the case, Sartre wanted to force negritude to universalise its vista and to metamorphose into the wider class struggle posited by Marxist eschatology. Negritude was in effect antiracist racism, a negation of racism. The poets of the negritude movement were the only people capable of recovering the authenticity of human experience. Recognising the sensitivities of asking black anticolonial movements to renounce the particularities of their experiences, Sartre qualified that the 'colored man-and he [sic] alone-can be asked to renounce the pride of his color' (1976b, 38).

Sartre's request that the negritude movement universalise its resistance led some to question his authority to serve as a spokesperson for third world' societies and to regard him as yet another well meaning but ultimately ignorant apologist from the metropolitan heartland (Haddour 2005). But, influenced hugely by the drift of Marxism in the Soviet Union into brutal and repressive Stalinism, Sartre refused to buckle and was keenly aware of the limitations of movements, organisations and institutions claiming to stand at the vanguard of emancipation. He continued to advocate an abandonment of the category of race and nation, once racial and national consciousness had been achieved. The 'Party', Sartre argued, was structured to become an end in itself and not a means to an end. It was part of the problem. And arguably the prevalence of despotism, militarism, fascism and dictatorship in many liberated colonies today suggests his caution was well founded.

Sartre wrote Vietnam, imperialism, and genocide in December 1967 in his capacity as Executive President of the Russell International War Crimes Tribunal (see Sartre 1983). For Sartre, Vietnam was the battleground on which history itself was being fought out. The United States was targeting Vietnam simply as a means of protecting capitalist interests everywhere. Meanwhile, by default, the Vietnamese were fighting on behalf of oppressed peoples everywhere.

When a peasant falls in his rice field, mown down by a machine gun, we are all struck. In this way the Vietnamese are fighting for all men, and the Americans against all men ... the American government is well aware the present act of genocide-as a reply to a people's war-is conceived and perpetuated in Vietnam not only against the Vietnamese but against humanity $\ldots$ in this sense imperial genocide can only become more radical-because the group aimed at, to be terrorized, through the Vietnamese nation, is the human group in its entirety. (Sartre 1974, 83)

In Istanbul in November 2005, and set within a wider critique of the neoconservative 'Project for the New American Century', a similar World Tribunal on Iraq was likewise conducted. Intriguingly, the World Tribunal on Iraq was inspired by and directly modelled on Sartre's fashioning of the Russell Tribunal.

\section{'Masses', 'spontaneity', 'Party': Sartre's theory of practical ensembles}

It is possible that Sartre's theory of colonialism has been indicted as metrocentric simply because critics have focused on what he was trying to do rather than on what he actually did. The objective of the Critique of dialectical reason was to establish a new basis for a Marxist theory of history and thereafter to cast the history of colonialism as a constituent moment in the general transition to Socialism. Sartre set out to establish that there could be a definitive totalisation (a socialist society), even though there was no overarching totaliser or hidden architect of history. But he failed in this task and as a consequence Volume 2 of the Critique was never completed. Sartre could only conclude that while totalising could exist (a continual abstraction from the particular to the universal), there could never be totalisation (a final universal resting point).

In this section we argue that with hindsight Sartre's failure might be the source of his redemption. Ironically, what Sartre deposited as a set of intellectual ruins, incapable of solving a central theoretical problem of the day, might by default form the basis of a theory of colonialism that dismantles the universalising tendencies of postcolonial theory. Our focus is on the Theory of practical ensembles Sartre offers in Volume 1 of the Critique. Here Sartre's insinuation of existentialism into the Marxist canon leads him to the conclusion that the aggregate consequence of molecular struggles for freedom and against oppression and alienation is a series of unpredictable and historically novel social, cultural and political collectives. Anti-colonial struggles cannot be reduced to constituent parts of a universal process, but rather emerge with their own history and along particular trajectories. 
For Buttimer (1993) the dramas of Western humanism are best captured in Promethean mythology in which the liberation cry of humankind unfolds in a trilogy, beginning with Phoenix, when new life emerges with vitality promising a new beginning; progressing through Faust when such life ossifies into a stifling and rigid organised institution; and ending with Narcissus the moment when self-perpetuating bureaucracies generate internal self-critique and a context is created for Phoenix to reassert its presence. In the Theory of practical ensembles, Sartre's existential roots draw him back to Prometheus but now, mediated by Marxism, his Phoenix, Faust and Narcissus bear the titles 'seriality', 'fusion' and 'metastases', or 'masses', 'spontaneity' and 'Party'. The sentiment may be the same, but this shift implies something more substantive.

At the heart of Sartre's social theory of alienation is the concept of material scarcity. In spite of claims about a world of abundance, absolute and certainly relative scarcity remains an endemic feature of human existence. Scarcity in turn mediates social relationships and is the primary motive for and vehicle through which the objectification of others takes place. For Sartre, scarcity was never formally theorised by Marx because it was simply assumed to define the rules of the game; it was nowhere in Capital because it was everywhere in Capital. Typical of his mode of argumentation, Sartre deploys the everyday example of people waiting at a bus stop for a bus with limited spaces. This situation for Sartre represented a structured management of scarcity - everything from the technology of buses to the systems of creating timetables - set the constituent conditions under which human relations are constructed. Competition for scarce resources results in a loss of humanity; the other is objectified as a threat to one's access to opportunities to appropriate and consume. The material world brings people, neighbourhoods, communities, cities, regions, nations and continents into competition with one another, and this competition is the source of the drive to dehumanise and objectify.

Sartre refers to those gatherings or 'masses' that shelter submissively under particular political and economic systems as groups in series. Groups in series are collectives rather than groups as such. Collectives fall prey to a particular existential condition that Sartre characterises as an 'atomisation of the crowd', a 'passive unity' or a 'plurality of solitudes'. Groups in series consist of isolated individuals, frozen and rendered inert by their material needs, and ultimately living out a life of alienation from their full creative potential. To be part of a group in series is to live a 'mode of being that consists of serial behaviour, serial feelings and serial thoughts' (Sartre 1976a, 266). Deposited into fossilised landscapes, serial populations live in a space or location Sartre would refer to as a practicoinert.

However inert life may seem for groups in series, eventually it is alienation and its transcendence that triggers movement. For Sartre, newness enters the world, not only in conditions it did not choose, but precisely because of conditions it did not choose. In the Theory of practical ensembles, Sartre sketches out a sequence of groupings he claims emerge from the depths of seriality in search of redemption. Occupying the premiere position in the emerging sequence is the cherished group in fusion, a kind of spontaneous and anarchic uprising and an effective movement for social change. The group in fusion both liquefies groups in series and then begins the task of reconstituting the now malleable collective into a more progressive form.

The processes through which groups in fusion emerge exercised Sartre enormously. He used the concept of the 'third party' as his central organising device. Consider two people attending to their gardens, he muses in typically Sartrean fashion, separated by a large opaque fence. Any union between these two activities is impossible until a third party, perhaps looking from an adjacent window, registers the situation and acts to effect synthesis. The continual expansion of third parties leads in turn to ever larger communions. The process is contingent and open, although also historically structured (a situation he also called 'rational'), and therefore it is indeed impossible to predict the form and trajectory of emerging groups in fusion. For Sartre then, a process totalising a multitude of acts of resistance can be accomplished without the help of any particular totaliser:

Consider a regroupment behind some shelter after a flight. Some individuals will not take part in it: the action of the enemy will have cut them off completely from any synthetic community. For them, seriality itself, which began in panic, has culminated in molecular exteriority: the individual, alone, cut off from Others, continues his [sic, and thereafter] flight, loses his way, hides in a cellar, gives himself up etc. ... While I am on my way up to join with the central core of resisters who are sheltering behind some building, I happen to 
be in the practical field of another third party, who is coming out of another street and approaching the same group with the same purpose and the arrival of this third party at the group has real, objective links with my own approach: for me he increases the multiplicity of resisters, thereby increasing the chances of success and diminishing my personal risks. This is the joyful surprise which all the assembled demonstrators feel when, on the occasion of a demonstration which has been forbidden by the police, they see individuals and small groups converging from every direction, more numerous than they had expected, and representing a hope to everyone. ... When I approach it to join it, I am already part of it. We have seen in what sense: as a limit of totalisation, as an impractical task which has to be done. And from this point of view the present multiplicity of the group constitutes me objectively as a member of a tiny group of desperate men who will get themselves killed on the spot, either as members of a huge invincible demonstration or as is more usual taking part in some intermediate formation. This internal synthetic constitution of me by the group is simply totalisation returning to me to give me my first common quality over the collapse of seriality. And it gives me this quality as power. Thus the third party comes to the group which already possesses him, as a constituent and constituted power; that is, he receives the power he gives, and he sees the other third party approaching him as his power. For in the group, the other third party, in so far as I totalise him with the others is not for me a third party object that is to say, a third party transcendent to me. As an individual he transcends me towards his projects in so far as I transcend him: this is simple reciprocity. ... In practice this means that I am integrated into the common action when the common practice of the third party poses itself as regulatory. I run with all the others; I shout: stop!; everybody stops. Someone else shouts lets go! Or to the left! To the right! To the Bastille! And everyone moves off, following the regulatory third party, surrounding him and sweeping past him. (Sartre 1976a, 374-80)

Seriality is perpetually on the brink of being liquefied but rarely succumbs to dissolution. The weight of the prevailing political and economic infrastructures that manage and mediate scarcity and the violence they promise for dissenters ensures that insurrection is stifled and suffocated. More often than not then, groups in fusion short circuit before they can grow to have any kind of impact. The result of their fleeting existence is the formation of mere islands of humanity in an inert series and only mini and partial guerrilla warfare on serial collectives.

For those groups that do survive, however, the central problem of scarcity resurfaces. The old sys- tem of resource distribution might have been toppled, but the group in fusion has to confront the reality that still there are not enough resource units and items of consumption to go around. Never solving the problem of scarcity - partly because historical conditions under capitalism actually work to create and re-imagine scarcity - those groups that do survive must crystallise and secrete new methodologies of resource allocation and rationing. Inequalities remain endemic and organisation of the administration of material goods is required lest disharmony lead to group implosion.

This process results in greater sophistication in the group's organisational structures. The group must organise or it will perish. The result is the formation of groups in metastases. Sartre spends considerable time looking at the ever more sophisticated degrees of structuredness of groups as they organise to secure their existence. There is no space here to review his sequence of groupings, nor the order he necessarily places them in, but it will suffice to note that they run from the fused group, through the sworn (or pledged) group, the statutory group, the organisation, the institution (state) and finally to social classes (for more detail, see Hartmann 1981). As structure becomes more imposing and forbidding, and as freedom movements become formalised and bureaucratised, new types of groups in series emerge. The means of violence, hitherto directed at the oppressor, then become an instrument of self-discipline and internal group control. The group ossifies back into an inert collective and agency peters out.

For Sartre, the metastases of the group in fusion into an ever yet more complex organism therefore unravels all the good that is initially done:

The group reacts to this permanent danger [of collapse] with new practices: it produces itself as an institutionalised group; which means that 'organs', functions, and powers are transformed into institutions; that, in the framework of institutions, the community tries to acquire a new type of unity by institutionalising sovereignty, and that the common individual transforms himself [sic] into an institutional individual. [The result] is degraded forms of community. 'Degrade', here does not, of course have anything to do with a system of values: I merely mean that the group - whose origin and end reside in an effort by the individuals who are gathered to dissolve seriality in themselves - will, in the course of its struggle, actually reproduce alterity in itself and freeze into the inorganic so as to struggle against it within. ... In other words, our dialectical investigation makes a turning here and goes back 
towards the practico-inert, from which it removed itself a little earlier; it is beginning to appear that the movement of the investigation may possibly be circular. (Sartre 1976a, 591)

History unfolds in a circular process of regrouping and petrification and thus holds out no ultimate solution to human alienation. Sartre describes this double movement or dialectical circularity as a 'circular synthesis of disorder of order and order of disorder' (Sartre 1991, 272).

In the absence of any utopian exit, Sartre would seem to be advocating the group in fusion as the only revelatory moment of emancipation, however fleeting. Perhaps for Sartre the best that might be hoped for is a world that is perpetually liquefying inert serialities, with groups in fusion constantly forming and collapsing and never growing to a level of complexity that undermines their cathartic potential. If this is the principle source of hope in Sartre's dialectic, then perhaps Stephen Priest $(2001,1)$ may well be correct in his assessment of Sartre's career as best conceived of in terms of the motif 'liberty, equality, and fraternity', referring respectively to his existentialist stage from the mid 1930s, his turn to Marxism in the 1950s, 1960s and 1970s, and his drift to anarchism just before his death in 1980.

The Theory of practical ensembles provides the basis of a theory of colonialism that refuses to conceive of anti-colonial movements as instances in a universal struggle destined to end with a transition to Socialism. Instead, it celebrates the local emergence of contingent, fluid, novel, hybrid and creolised cultural and political forms. Sartre departs from historicism and is led to a circular history that approaches separate colonialisms as distinctive, unique and incommensurable with universal abstraction. Resistance is most liberating at that moment when unpredictable, volatile, historically unique, and often unnameable social, cultural and political movements emerge; and most tyrannical when attempting to unify and aggregate these movements into organised, fossilised and crystalline bureaucracies and institutions. Freedom is to be found amidst struggle, not as an après.

\section{Sartre's historicised phenomenology of existence as spatial}

In this final section we argue that Sartre's departure from metrocentric universal theorising and in particular from metrocentric reifications of historicism derives from his novel and provocative recognition of the importance of spatiality. It is perhaps surprising that so few Anglo-American geographers have studied Sartre's thinking on space seriously. Samuels' (1978 1981) pioneering work introduced Sartrean existentialism to the humanistic tradition that emerged in the 1970s. Kobayashi (1989) identified Sartre as a central figure around which humanistic geography and Marxism might be fused, and later highlighted the importance of Sartre's treatment of spatiality for geographies of racism (Kobayashi 2004). Jamieson (1961) brought Sartre to the attention of Marxist Geographers, particularly those interested in theorising capitalism and the postmodern condition (see for instance, Boyle 2005; Harvey 1989; Soja 1989). Judith Butler has woven Sartrean thought into theories of performativity that have become important for nonrepresentational geographies (for a useful summary of Butler's indebtedness to Sartre, see Busch 1999). Davidson (2003) has located Sartre's existentialism at the heart of emerging geographies of emotion and affect. Doreen Massey has recognised the importance of Sartre in the historical geography of the emergence of modernity's discovery of the idea of 'space-time' (Massey 2005). These interventions notwithstanding, geographers have by and large failed to excavate and scrutinise Sartre's approach to spatiality. It is unsurprising then that only Peet (1998) and Blunt and Wills (2000) ascribe to Sartre any significant role in the history of the discipline and even then he attracts only subsidiary commentary in these texts.

A feature of Sartre's early work that has been largely overlooked is that his concept of being is fundamentally spatial and relative. That is, human existence occurs always in relation to others who are set at a distance from the self; that distance constitutes the recursive relationships that are the basis for both individual and social existence. As Martin Buber once put it, the fundamental human condition is established through the separation between human beings - distance, alterity, otherness - as a basis for human relationship. Engagement of the other, which Sartre describes as 'the look', involves objectification and placement of the other body, its setting at a distance from the self, as a mutually constitutive project that is fundamentally spatial, as well as the basis for relationships of power between human beings: 
My own look or my connection without distance to these people is stripped of its transcendence by the very fact that it is a look-looked-at. I am fixing the people whom I see into objects; I am in relation to them as the Other is in relation to me. In looking at them I measure my power ... My look simply manifests a relation in the midst of the world, a relation of myself-as-object to the object-looked at - something like the attraction which two masses exert over one another at a distance.

... In so far as I am looked at I do not unfold the distance, I am limited to clearing it. The Other's look confers spatiality on me. (Sartre 1943, 242)

Sartre's discussion of the look is key to understanding the ways in which distance (measured in any number of ways, but always - even in its metric form - as a constructed quality of relationship), or the act of setting the other at a distance, is the geographical basis for othering, through the construction of class, gender, ethnicity, race, territory, sexuality, age, disability and so on. Distance, or alterity, ironically constitutes the human capacity for recognising both the self and the other, and the profound basis (in its objectification of the other) for oppression. Spatiality is thus the form of human relationship. There is no abstract or objective 'space' to be filled, only the active filling of the world. To be human is to spatialise. To engage with others is to spatialise the other in relationship. Perhaps Sartre's most important contribution to the understanding of the importance of spatiality to the human condition, always a recursive and discursive, or relational, condition, is: 'To apprehend oneself as looked at is to apprehend oneself as spatializing-spatialized' (Sartre 1943, 242). What more profound encapsulation of the ontological significance of the concept of spatiality could geographers ask for?

Sartre's phenomenology of being as spatial is retained and developed in his later writings, and not surprisingly underpins and infuses his writings on the future of Marxism and the meaning of colonialism and anti-colonialism in history. Sartre's phenomenology now becomes imbricated into his historical materialism and a historicised phenomenology of spatial existence is developed. In Being and nothingness, Sartre had already insisted that consciousness is intentional insofar as consciousness is always consciousness of something. The anatomy of consciousness then is contaminated by and bears the imprint of the 'situation' in which the human being dwells. In the Critique, spatiality continues to be treated as intentional, but greater con- cern was now registered with unpacking the rather crude idea of the 'situation'. Deposited into particular social and historical contexts, the 'look' is put into play by different groups in different ways towards different ends with different outcomes. In other words the human condition of spatiality becomes concretised with different consequences depending on prevailing social and historical conditions.

The result is necessarily and profoundly a spatial, material landscape, in which spatiality is defined not only as the recursive relationship between human beings, spatialising/spatialised, but also the relationship between human beings and things. Things, or matter, are the product of human labour, produced historically, and given meaning in a process that Sartre calls 'totalizing totalized'. That is, the mediation of the material world by human action both signifies and alienates the material products of history in a double dialectic. Praxis is a material act that gives meaning to the world, conditioned by the 'passive unity of prefabricated meanings' in which 'there are no material objects that do not communicate among themselves through the mediation of men [sic]; and there is no man [sic] who is not born into a world of humanised materialities' (1976a, 169). But praxis is also alienated as matter acts back on the actor, resulting in what Sartre calls the complex fact of 'accumulation outflow', or the creation of material conditions that turn praxis back on itself, dissolving individual actions in their exteriority, in the process creating a landscape of uneven scarcity and contested meanings.

Sartre's historicised phenomenology of spatial existence underpins his theory of colonialism. Ways of looking are both a product of and modality through which particular formations of the colonial become possible, through particular forms of human relationship (spatialising-spatialised) and in particular landscapes (accumulation outflow). Sartre conceives of the different groups that form and dissolve at different stages in the process of colonialisation - namely groups in series, groups in fusion and groups in metastases - as founded on, practising and reproducing different ways of being spatial. We refer to these historicised phenomenologies as: spatiality as tyranny, spatiality as liberation and spatiality as incarceration. We argue that the originality of Sartre's postcolonial geography rests on his claim that different ways of looking (or 
objectifying the other) mediate and in turn are mediated by successive waves of colonial expansion, contestation and retreat, and his assertion that because ways of looking are interrelated and organised in a particular causal sequence, colonial projects unfold in a circular way.

Sartre's concept of the group in series captures precisely the existential condition of the colonial subject. As colonial powers engage in territorial conquest and annexation, the 'look' performs as an act of tyranny, projecting poisonous hierarchies of civilisations, levels of humanity and degrees of barbarism. Colonialism alienates both colonising and colonised populations and renders both inert. Out of the depths of this apparatus arises a new, dynamic, open and turbulent spatiality. Fused groups or groups in fusion depend on and in turn reproduce new ways of looking - a restless, dynamic, fluid and radical openness to transient coordinate systems, always being reconfigured, recalibrated and rescaled. Third parties chronically and continually totalise strands of insurrection. Historically novel social, cultural and political resistances emerge. Spatiality as liberation has a short life expectancy, however, and can only survive by ossifying into a new dispensation. Spatiality as incarceration then dominates, as freedom movements degenerate into crystalline forms, equally oppressive as the powers they were born to remove. The spontaneity of the group in fusion gives way to fratricidal imprisonment and incarceration. Groups in metastases work to incorporate, bureaucratise, count, regulate, discipline and police internal threats. The dominant existential condition of this age is one of paranoia and the sense that one is under constant surveillance.

\section{Conclusion}

Very few scholars have taken literally and seriously the formal and specific theoretical architecture Jean-Paul Sartre erected in his efforts to make sense of and to resist colonialism. For a range of Leftleaning anti-capitalist, anti-globalisation, environmental, anti-war and anti-fascist social movements at least, Sartre is no antique, historical curiosity, or mere footnote in the history of thought. But even among these constituencies his influence is largely derivative, mediated and oblique, defined primarily by the tone and colour of his prose, and by his personality, reputation and aura. Within AngloAmerican geography, interest in Sartrean Existen- tialism and Sartrean Existential Marxism largely waned with the rise of poststructuralism and the linguistic turn, the rejection of the possibility of searching in any meaningful way for a telos to history, and with the ascendancy of postmodernism and the marginalisation of grand theorising. In the stampede to claim new ground, crude caricatures were drawn and Sartre steadily became branded as 'outdated', 'unfashionable', 'passé' and 'redundant'. In aggregate, Sartre casts a ghostly spectre or looming shadow over postcolonial studies, formative of the collective consciousness and conscience, but in truth buried from public view and academic scrutiny.

It is therefore somewhat unfortunate that Sartre is now being indicted as a central point of origin of postcolonial theory's embroilment in a debilitating Western historicism. This article has sought to clarify the case for and against framing Sartrean thought as Eurocentric or metrocentric in spite of itself. It has attempted to recover Sartre's theory of colonialism and to use Sartre, twentieth-century Paris and the politics of the twentieth-century French colonial adventure, to make a case for a reinvigorated interest in the differentiated forms of European modernity and the complex and contradictory theoretical enterprises these forms have deposited. Here our project both consolidates Massey's (2005) clarion call for a historical-geographical excavation of formulations of time and space in European modernity and extends this project by foregrounding theories of colonisation as both constituted by and constitutive of such formulations. Our objective is not to reassert the virtue of European modernity and its theoretical premises in any uncritical way, but instead to hold open the possibility that within certain contexts we can still learn important, progressive and useful lessons from certain theories of colonialism with European parentage.

We argue that caught up in the maelstrom of twentieth-century Parisian intellectual and political life, Sartre in fact displayed a complex relationship with metrocentric theoretical projects and practices. He provided a theory of practical ensembles that replaced Marxism's eschatology and linear teleology with a series of circular histories based on the complex ways in which separate anti-colonial movements spiral off following their own contingent, creolised and anarchic trajectories. We identify his strong commitment to spatiality, developed into a historicised phenomenology of existence as 
spatial, as tempering and ultimately undermining his commitment to historicism. In the end Sartre could not establish a basis for a Marxian dialectic, but instead did see the progressive political implications of recognising the workings of a socio-spatial dialectic that pivoted around such notions as happenstance juxtapositions, throwntogetherness, perpetual fusion and the continuous search for new third parties.

In calling for a formal and serious investigation and comprehension of the nuances and intricacies of Sartre's scholarship and politics, in the final analyses we are not offering Sartre as a solution to historicism. Sartre's theory of colonialism ultimately begins with the assumption that the history of colonial populations has been jump started' in important ways by colonialism. Sartre does not provide a means of recovering subaltern historiographies so as to purge colonised populations of their European unconscious or to recover their 'authentic' pre-colonial identities. Sartre's approach falls well short of recognising that the entanglement of colonising and colonised biographies is mediated by multiple modalities of power; class, race and ethnicity for sure, but also gender, age and sexuality. Histories of capitalism and colonialism will only ever be partially captured by Sartrean theoretical constructs and we cannot deploy Sartre's theory of colonialism in any sense as a convincing overarching explanatory framework.

Nevertheless we conclude that it is simply wrong to designate the broad collection of scholars often categorised as 'structuralist', 'poststructuralist' $^{\prime}$ or 'postmodernist' as fundamentally antiSartrean or post-Sartrean and complex genealogies, intellectual entanglements and lines of continuity remain to be excavated and appreciated. Sartre's intellect was creative and nomadic, and he proves fascinating in part as a result of his complexities, nuances, contradictions, quirks and ambivalences. We too insist on preserving the unclassifiability and sheer strangeness of Sartre's approach. We find ourselves in sympathy with Fox (2003), who paints Sartre as a schizophrenic thinker, traversing modernity and postmodernity, and offering simultaneously: a theory of the subject that walks a tightrope between the idea of the Cartesian, rational, unified, autonomous subject, and the socially and linguistically decentred, fragmented and multiple subject; a theory of history that fluctuates between macro-theoretical, universalising and totalising claims, and micro-theoretical contingent, indeterminate and detotalised visions that challenge simple causality and linearity; and a politics that incorporates both universal struggles over political economy and the state and 'superstructural' concerns with locality, difference, culture and identity.

How might one account for the seeming disjuncture between the nuanced interest in the local, the contextual and the contingent in Sartre's more considered theoretical works and philosophical ruminations and the universal, bold, often crude and sweeping claims advanced in Sartre's speeches, public proclamations and political activism? Of course, it has to be remembered that many of Sartre's statements were designed to draw maximum publicity, and his most crude and stark tendencies towards universal grand claims say more about his desire to access the public domain than about his thinking per se. Sartre too struggled to read all substantive colonialisms through a Marxist lens. His more considered statements reveal greater complexity in his analyses and a preparedness to treat aberrant cases as a problem for his theory and not just as rogue outliers. Paolucci (2007), for instance, presents a close reading of Sartre's writings on Cuba and his visit to the island in 1960. She concludes that Sartre saw in the youthful Cuban revolution a species of socialism that was centred on the freedom of the human person and not the tyrannical encrustations of a fossilised Communist Party. In fact, Sartre could not reconcile the Cuban revolution with Marx's universal and abstract categories: to his own astonishment he declared: 'But this is not Marxism!' Sartre became interested in historically grounded insights on potential pathways to revolutionary praxes and came close to renouncing dogmatic, prefabricated models of social change, which ultimately imprisoned freedom. Once the complexities of Sartre's theoretical musings have been rediscovered and digested it will be necessary to re-read the corpus of his substantive writings and political activism, and it is probable that an entirely more nuanced set of insights will be gleaned.

Sartre now sleeps, but his sleep cannot be but troubled. It is perhaps time to dust down the debris of 50 years or more of neglect and partial, selective and at times outright misunderstanding and misappropriation, and to consider anew what Sartre might bequeath to postcolonial studies today and to critics of the colonial present. 


\section{Acknowledgements}

The authors would like to thank Alison Blunt, three anonymous referees, James Sidaway, Mary Gilmartin, Gavin Titley, Karen Till, Gerry Kearns and Ato Quayson, who provided valuable comments on an earlier draft of this paper. Versions of the paper were presented at research seminars in York University in Toronto $(2009,2010)$, the First International Political Geography Colloquium in Reims (2008), the Association of American Geographers Conference in Las Vegas (the Antipode James Blaut Memorial Lecture) (2009), and the annual meeting of Irish Geographers in Maynooth (2010).

\section{Note}

1 Title taken from an interview conducted with Jean Paul Sartre on 27 August 1969 in Rome and published in 1970 in the Socialist Register 7 233-49.

\section{References}

Alleg H 1958 La question Editions de Minuit, Paris

Aron R 1975 History and the dialectic of violence: an analysis of Sartre's critique de la raison dialectique Blackwell, Oxford

Aronson R 1987 Sartre's second critique University of Chicago Press, Chicago IL

Aronson R 2004 Camus and Sartre: the story of a friendship and the quarrel that ended it University of Chicago Press, Chicago IL

Badiou A 2007 The event in Deleuze Parrhesia 2 37-44

Blunt A and McEwan C eds 2002 Postcolonial geographies Continuum, London

Blunt A and Wills J 2000 Dissident geographies: an introduction to radical ideas and practice Prentice Hall, Harlow

Boyle M 2005 Sartre's circular dialectic and the empires of abstract space: a history of space and place in Ballymun, Dublin Annals of the Association of American Geographers 95 181-20

Busch T W 1999 Circulating being: from embodiment to incorporation: essays in late existentialism Fordham University Press, New York

Buttimer A 1993 Geography and the human spirit John Hopkins University Press, Baltimore MD

Camus A 1992 The rebel: an essay on man in revolt Vintage Books, London

Catalano J S 1986 A commentary on Jean Paul Sartre's critique of dialectical reason vol 1: theory of practical ensembles University of Chicago Press, Chicago IL

Chakrabarty D 2007 Provincialising Europe: postcolonial thought and historical difference (new edition) Princeton University Press, Princeton IL

Chiodi P 1976 Sartre and Marxism The Harvester Press, London
Cohen W B 2003 The Algerian War and the revision of France's overseas mission French Colonial History 4 22739

Cooper F 2005 Colonialism in question: theory, knowledge, history University of California Press, Berkeley CA

Craib I 1976 Existentialism and sociology: a study of Jean Paul Sartre Cambridge University Press, Cambridge

Davidson J 2003 Phobic geographies: the phenomenology of spatiality and identity Ashgate, Aldershot

Fatouros A A 1965 Sartre on colonialism World Politics 17 703-19

Flynn T R 1997 Sartre and Foucault: toward an existentialist theory of history Vol 1 University of Chicago Press, Chicago IL

Fox N F 2003 The new Sartre Continuum, London

Gerassi J 1989 Jean Paul Sartre: hated conscience of his century vol 1: protestant or protestor? University of Chicago Press, Chicago IL

Haddour A 2005 Sartre and Fanon: on negritude and political participation Sartre Studies International 11286 301

Hartmann K 1981 Sartre's theory of practical ensembles in Schilpp P A ed The philosophy of Jean Paul Sartre Open Court, Illinois 631-60

Harvey D 1989 The condition of postmodernity Blackwell, Oxford

Jamieson F 1961 Sartre: the origins of a style Yale University Press, New Haven CT

Jeanson F 1952 Critique de l'Homme révolté d'Albert Camus Temps modernes 79 15-23

Kearns G 2009 Geopolitics and empire: the legacy of Halford Mackinder Oxford University Press, Oxford

Kelly M 1999 Towards a heuristic method: Sartre and Lefebvre Sartre Studies International 5 1-15

Kobayashi A 1989 A critique of dialectical landscape in Kobayashi A and Mackenzie S eds Remaking human geography Unwin Hyman, London 164-83

Kobayashi A 2004 Geography, spatiality, and racialisation: the contribution of Edward Said Arab World Geographer 7 79-90

Lawler J P 1976 The existentialist Marxism of Jean Paul Sartre BR Gruner Publishing Co, Amsterdam

Majumdar M A 2007 Postcoloniality: the French dimension Berghahn Books, London

Massey D 2005 For space Sage, London

McBride W L 1981 Sartre and Marxism in Schilpp P A ed The philosophy of Jean Paul Sartre Open Court, Illinois 605-30

McEwan C 2008 Postcolonialism and development Routledge, London

Merleau-Ponty M 1955 Les aventures de la dialectique Gallimard, Paris

Merleau-Ponty M 1990 Humanism and terror: an essay on the Communist problem Beacon Press, Boston

Mignola W D 1995 The darker side of the renaissance: literacy, territoriality, $\mathcal{E}$ colonization University of Michigan Press, Michigan IL 
Minca C 2003 Critical peripheries Environment and Planning D: Society and Space 21 160-8

Nash C 2004 Postcolonial geographies: spatial narratives of inequality and interconnection in Cloke P, Crang $\mathbf{P}$ and Goodwin $\mathbf{M}$ eds Envisioning human geographies Arnold, London 187-216

Paolucci G 2007 Sartre's humanism and the Cuban revolution Theory and Society 36 245-63

Peet D 1998 Modern geographical thought Blackwell, London

Pickles J 2005 'New cartographies' and the decolonisation of European geographies Area 37 355-64

Pollard J, Nina L, McEwan C and Stenning A 2009 Economic geography under postcolonial scrutiny Transactions of the Institute of British Geographers NS 34 137-42

Poster M 1975 Existential Marxism in postwar France: from Sartre to Althusser Princeton University Press, Princeton NJ

Priest S 2001 Jean-Paul Sartre: basic writings Routledge, London

Said E 1978 Orientalism Vintage, New York

Said E 2000 My encounter with Sartre London Review of Books 1 June 1-3

Samuels M S 1978 Existentialism and human geography in Ley D and Samuels M S eds Humanistic geography: problems and prospects Marooufa Press, Chicago IL 22-40

Samuels M S 1981 An existential geography in Harvey M $\mathbf{E}$ and Holly $\mathbf{B} \mathbf{P}$ eds Themes in geographic thought Croom Helm, London 86-106

Santoni R 2003 Sartre on violence: curiously ambivalent Pennsylvania State University Press, University Park PA

Sartre J-P 1943 Being and nothingness: an essay on phenomenological ontology Routledge, London

Sartre J-P 1945 L'âge de raison Gallimard, Paris

Sartre J-P 1945 Le sursis Gallimard, Paris

Sartre J-P 1946 Anti-Semite and Jew Schocken Books, Paris

Sartre J-P 1949 La mort dans l'âme Gallimard, Paris

Sartre J-P 1955 Materialism and revolution Criterion Books, New York

Sartre J-P 1961 Le procès du réseau Jeanson Maspero, Paris

Sartre J-P 1964 The problem of method Methuen, London
Sartre J-P 1966 Situations IV: Merleau-Ponty Fawcett, Greenwich

Sartre J-P 1969 The Communists and peace Hamilton, New York

Sartre J-P 1974 Between Existentialism and Marxism: Sartre on philosophy, politics, psychology, and the arts Pantheon Books, London

Sartre J-P 1976a Critique of dialectical reason vol 1: theory of practical ensembles New Left Books, London

Sartre J-P 1976b Black Orpheus French and European Publications, London

Sartre J-P 1983 Vietnam, imperialism, and genocide in Sartre J-P Between Existentialism and Marxism Verso, London 67-83

Sartre J-P 1988 What is literature? And other essays Harvard University Press, Cambridge, MA

Sartre J-P 1998 Merleau-Ponty vivant in Stewart J ed The debate between Sartre and Merleau-Ponty Northwestern University Press, Illinois 565-626

Sartre J-P 1991 Critique of dialectical reason vol 2: the intelligibility of history Verso, London

Sartre J-P 2001 Colonialism and neo-colonialism Routledge France, Paris

Senghor L S 1948 Anthologie de la nouvelle poésie nègre et malgache Puf, Paris

Sidaway J 2000 Postcolonial geographies: an exploratory essay Progress in Human Geography 24 591-612

Soja E 1989 Postmodern geographies: the reassertion of space in social theory Verso, London

Spivak G-C 1981 French feminism in an international frame Yale French Studies 62 154-84

Stewart J 1998 The debate between Sartre and Merleau-Ponty Northwestern University Press, Chicago IL

Wehrs D R 2003 Sartre's legacy in postcolonial theory; or, who's afraid of non-western historiography and cultural studies? New Literary History 34 761-89

Withers C W J 2007 Placing the enlightenment: thinking geographically about the age of reason University of Chicago Press, Chicago IL

Young R 2001 Sartre: the African philosopher in Sartre J-P Colonialism and neo-colonialism Routledge, Paris 1-18 